\title{
Erratum to: The majority of patients with long-duration type 1 diabetes are insulin microsecretors and have functioning beta cells
}

\author{
Richard A. Oram • Angus G. Jones • Rachel E. J. Besser • \\ Bridget A. Knight • Beverley M. Shields • Richard J. Brown • \\ Andrew T. Hattersley • Timothy J. McDonald
}

Published online: 19 November 2013

(C) Springer-Verlag Berlin Heidelberg 2013

\section{Erratum to: Diabetologia}

DOI 10.1007/s00125-013-3067-x

The authors would like to correct errors in the legend for

Figure 2 and in Table 1. The corrections are shown in red font.
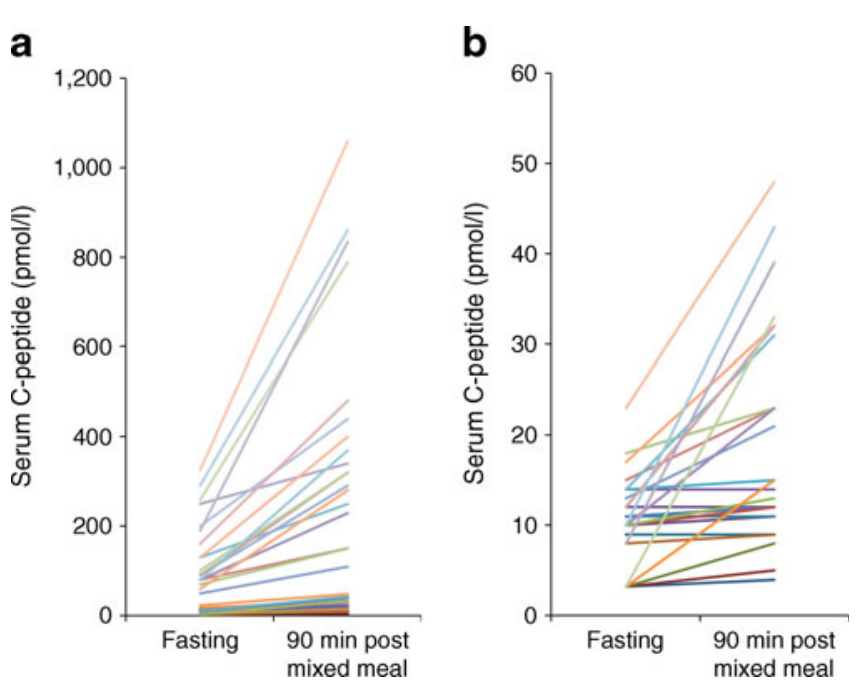

Fig. 2 The effect of a meal stimulus on serum C-peptide levels in participants with detectable insulin $(n=54)$. (a) Paired fasting and mixed meal results for all patients with detectable C-peptide. Each line represents an individual patient. (b) Results for all patients with fasting C-peptide below $30 \mathrm{pmol} / 1(n=36)$. Of 54 patients, $43(80 \%)$ had a serum $\mathrm{C}$-peptide value that rose after the mixed meal. None had a fall in the $\mathrm{C}$-peptide value after the meal

The online version of the original article can be found at http://dx.doi.org/ 10.1007/s00125-013-3067-x.

R. A. Oram • A. G. Jones · R. E. J. Besser • B. A. Knight •

B. M. Shields $\cdot$ A. T. Hattersley $(\bowtie) \cdot$ T. J. McDonald $(\square)$

NIHR Exeter Clinical Research Facility, University of Exeter

Medical School, Barrack Road, Exeter, UK

e-mail: A.T.Hattersley@ex.ac.uk

e-mail: Timothy.mcdonald@nhs.net

R. J. Brown · T. J. McDonald

Department of Blood Sciences, Royal Devon and Exeter NHS

Foundation Trust, Exeter, UK
Table 1 Summary data for serum and urinary C-peptide results using the Roche assay

\begin{tabular}{llll}
\hline Variable & $n$ & Median (IQR) & $\begin{array}{l}\text { Detectable C-peptide } \\
\text { percentage (fraction) }\end{array}$ \\
\hline $\begin{array}{c}\text { Fasting serum C-peptide } \\
\quad(\mathrm{pmol} / \mathrm{l})\end{array}$ & 74 & $11(0-30)$ & $66(49 / 74)$ \\
$\begin{array}{c}\text { Serum C-peptide at } 90 \mathrm{~min} \\
\quad \text { after MMTT (pmol/1) }\end{array}$ & 74 & $12(0-63)$ & $73(54 / 74)$ \\
$\begin{array}{c}\text { Fasting UCPCR from 2nd } \\
\quad \text { voiding (nmol/mmol) }\end{array}$ & 72 & $0.01(0-0.08)$ & $68(49 / 72)$ \\
$\begin{array}{c}\text { UCPCR at } 120 \text { min after } \\
\quad \text { MMTT (nmol/mmol) }\end{array}$ & 74 & $0.03(0-0.18)$ & $68(50 / 74)$ \\
$\begin{array}{c}\text { UCPCR after home meal } \\
(\mathrm{nmol} / \mathrm{mmol})\end{array}$ & 72 & $0.01(0-0.09)$ & $68(49 / 72)$ \\
\hline
\end{tabular}

MMTT, mixed-meal tolerance test 